DOI: 10.17707/AgricultForest.62.3.02

\author{
Nadežda STOJANOVIĆ, Mirjana OCOKOLJIĆ, \\ Vesna ANASTASIJEVIĆ, Nebojša RALEVIĆ, \\ Milorad VESELINOVIĆ, Nevena VASILJEVIĆ ${ }^{1}$
}

\title{
THE IMPACT OF ROADSIDE GREEN SPACES ON ECOLOGICAL CONDITIONS IN THE URBAN ENVIRONMENT
}

\begin{abstract}
SUMMARY
Automobile traffic, which is considered one of the key permanent sources of different types of urban pollution, particularly contributes to environmental problems linked to cities. Negative environmental impacts produced by city traffic can be significantly reduced through the establishment of roadside green spaces along city roads. This paper examines the impact of roadside green spaces grouped according to their urban biotope type, on ecological factors with the highest impact on human comfort, including temperature, humidity, city noise intensity and wind speed. The results and conclusions of this paper provide guidelines that can be applied in urban environmental planning and the design of open urban spaces.
\end{abstract}

Keywords: ecological impact, urban biotopes, roadside green spaces, urban forestry.

\section{INTRODUCTION}

The expansion of urban landscapes accompanied by uncontrolled and unplanned urbanization has led to a series of environmental problems faced by cities of today. Automobile traffic, as one of the key sources of different types of permanent pollution in the urban environment particularly contributes to the environmental problems of cities. Large areas covered by asphalt which are occupied by city roads cause overheating, increasing the heat island effect in cities, while reducing humidity in their immediate vicinity. Due to high vehicle frequency, the amounts of pollutants and noise intensity are increased, while changes in terrain configuration caused by road routing can, among other things, cause an increase in wind speed (Taha, 1997).

The establishment of roadside green areas is one of the major strategies aimed at the reduction of negative environmental effects caused by urban traffic. Greenery along city roads can help reduce the negative effects of warming through its positive impacts on ecological microclimate conditions by creating

1 Nadežda Stojanović, (corresponding author: nadezda.stojanovic@sfb.bg.ac.rs), Mirjana Ocokoljić, Vesna Anastasijević, Milorad Veselinović, Department of Landscape architecture and horticulture, Faculty of Forestry, University of Belgrade, Kneza Višeslava 1, 11000 Belgrade, SERBIA, Nebojša Ralević, Department of Agroeconomy, Faculty of Agriculture, University of Belgrade, Nemanjina 6, 11000 Belgrade, SERBIA, Milorad Veselinović, Institute of Forestry, Kneza Višeslava 3, 11000 Belgrade, SERBIA.

Notes: The authors declare that they have no conflicts of interest. Authorship Form signed online. 
the effect of cooling, while increasing overall urban comfort ( Potchter et al., 2006, Zoulia et al., 2009; Georgi et al., 2010).

The use of green spaces and other landscape elements has primary importance for protection against urban noise. Soft litter of fallen leaves reduces the intensity of low-frequency sounds by absorbing their energy (Aylor, 1972), while leaves and trees help in the reduction of city noise intensity by bouncing high-frequency sound waves (Aylor and Marks, 1976). Trees can reduce pollutants from the air by absorbing particles from the atmosphere (Nowak et al., 2006). On the other hand, the presence of green spaces and greenery massifs affects air movement, causing the effect of wind force reduction, not only at the system itself but also at a certain distance (Rosenberg, 1974).

Surely, green spaces have an impact on the ecological conditions in urban areas. It is of great importance for the planning and management of urban green areas to have information on the size, dendrological structure and biophysical characteristic of green spaces that provide the best results in the modification of unfavourable environmental factors. In addition, in the early nineties of last century, due to the increasing urge to solve environmental problems of urban areas, the need was recognized to put planning and management of urban landscapes in the ecological context.

In other words, the need arose to observe the city as an ecosystem composed of its basic topographical units in ecology - biotopes. A biotope is often defined as an ecological landscape unit, characterized by particular conditions and specific populations of biota (Qui et al., 2010). The ecological division of urban landscapes into basic ecological units - biotopes greatly contributed to a clearer and more applicable methodology of research into the impacts of green spaces on environmental factors modification in the urban environment.

The registration of urban biotope types, their spatial distribution in the urban landscape, familiarity with site conditions and the evaluation of their ecological impacts constitute an important and indispensable basis for urban area planning. This paper presents a preliminary research of the impacts of roadside green spaces along the main city routes in the Belgrade are grouped according to their urban biotope type on environmental factors with the highest impact on human comfort in cities, including temperature and humidity, city noise intensity and wind speed. The study of environmental impacts of green spaces categorized according to their urban biotope type has a special added significance in the overall planning and management of urban geen areas.

\section{MATERIAL AND METHODS}

The research of ecological functions of green spaces along city roads is based on the monitoring and measurement of the following environmental factors: temperature, humidity, city noise intensity and wind speed in isolated green spaces along the main city routes in the Belgrade area. 
A total of 15 main routes were recorded (Zrenjaninski road, Višnjička Street, Jurija Gagarina Street, Partizanski road, King Alexander Boulevard, Rakovički road and Patrjarha Dimitrija, Boulevard JNA, the Ibar highway, Nikola Tesla Boulevard, Mihajlo Pupin Boulevard, Tošin bunar, Pančevački road, Savski road, highway E-75, Batajnički road and Cara Dušana Street) in the Belgrade city area (borders of the Master Plan of Belgrade, 2021). The research was conducted on a total of 38 representative green spaces distinguished along these city routes (Figure 1).

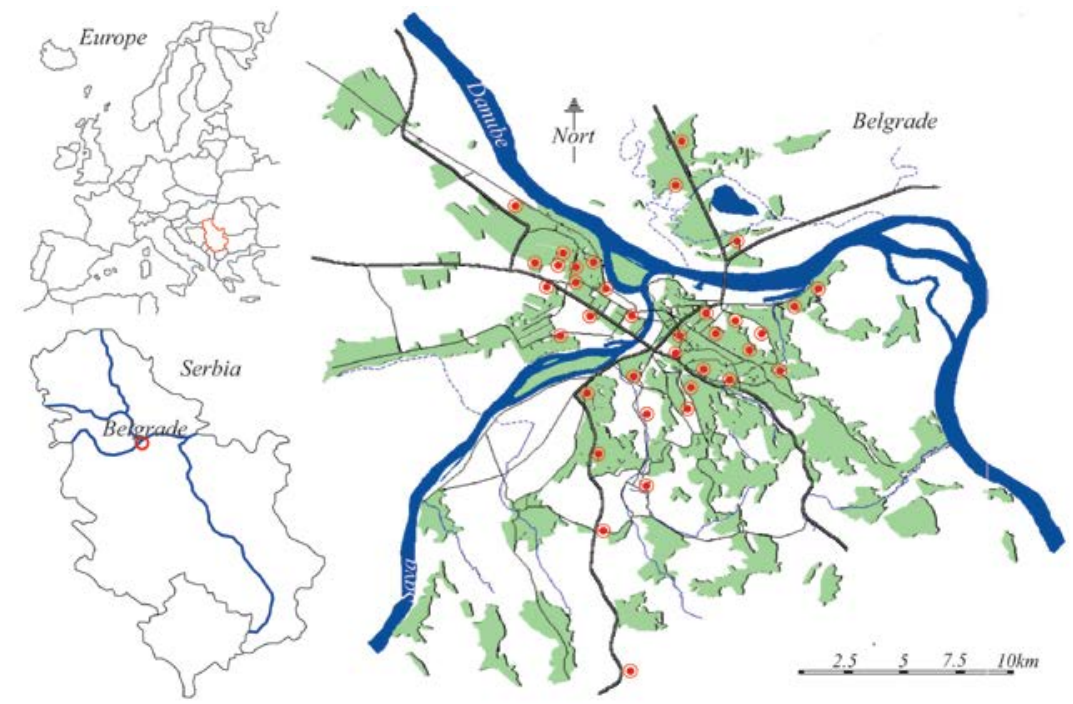

Figure 1. A schematic representation of the positions of selected green spaces along the main city routes in Belgrade (Source: A Modified map of residential and industrial areas from the Ecological Atlas of Belgrade)

The representative green spaces were selected on the basis of the following criteria: (1) Urban biotope type - The information basis for determining urban biotope types were results of the project "Belgrade Green Regulation" (2007), i.e. its Phase III "Mapping and Evaluation of Belgrade Biotopes". For the purpose of mapping or photo interpretation, a biotope is a clearly bordered area with a relatively unique structure of vegetation and use. The map of Belgrade biotopes was produced at the third hierarchical level of biotope typology, i.e. at the subtype level on the basis of a key for biotope mapping using the photointerpretation method. According to the established typology of Belgrade biotopes, the investigated main routes belong to the biotope of traffic structures without green spaces along roads. Therefore, for the purpose of this study, it was necessary to determine the biotope types of green spaces along the main city routes in Belgrade. According to the Map of Belgrade, these green spaces belong to three urban biotope types: urban fallows, green structures and thickets, groves and forests, which are considered to be a protective belt. The biotope type of green structures includes more or less arranged green areas with a certain level of 
maintenance. Urban fallows include various sites commonly overgrown with ruderal flora and vegetation. These spaces are subject to human impacts and unproductive. Thickets, groves and forests include all surface and line structures of trees or shrubs outside closed forests, as well as any residual forests on areas smaller than 0.5 ha which do not belong to a particular type of forest or forest plantation.

(2) Accessibility and availability in the field; The selection of green spaces for investigation included areas where the necessary measurements of environmental factors could be carried out over a long period of time (public and private property; accessible in the field). The research of ecological functions of the selected green areas was carried out during two research years. In each of the 38 representative green spaces measurements were performed during spring, summer and autumn of every research year in 3 series of 2 consecutive measurements, while control measurements were conducted in a series of 3 consecutive measurements. The total number of measurements was 5472, i.e. 5700 with control measurements. The measurements of air temperature, humidity and city noise intensity were performed with a digital weather station DT-8820 CEM, UK (operating measurement range: for air temperature from $-20^{\circ} \mathrm{C}$ to 750 ${ }^{\circ} \mathrm{C}$ with a $0.1^{\circ} \mathrm{C}$ resolution; for humidity from $25 \%$ to $95 \% \mathrm{RH}$ with a $0.1 \% \mathrm{RH}$ resolution; for city noise intensity from 35 to $130 \mathrm{~dB}$ with a $0.1 \mathrm{~dB}$ resolution). Wind speed was measured using an AM 4220 - LUTRON, Taiwan digital anemometer with a wind vane (operating range from 0.9 to $35 \mathrm{~m} / \mathrm{s}$ with a $0.1 \mathrm{~m} / \mathrm{s}$ resolution). Measurement readings were performed at two locations, i.e. in front of the green space (side toward the road) and behind that green space. All measurements were conducted on weekdays, in the morning, and at the operational height of $130 \mathrm{~cm}$ at each measurement point. In the aim of determination of the impact of green spaces on the environmental factors air temperature and humidity, a series of control measurements were carried out at identical distances in the direction of measurement points, both in the immediate vicinity and in open spaces without established plantings. When measuring temperature and humidity, the instruments were placed under a shield, whereas a microphone shield was used to neutralize the impact of wind on city noise intensity. The impact of green areas, i.e. the mean difference in air temperature and humidity was obtained as the difference between the mean values measured in front of the investigated green spaces and behind them and the mean values of differences in control measurements. When the environmental factors of city noise intensity and wind speed are concerned, the impact of green areas is represented as the mean value of differences in these factors measured in front of the investigated green spaces and behind them.

The reasearch was conducted in the aim of: 1) determination of the level of impact of roadside green spaces classified according to their urban biotope type on environmental conditions in their immediate urban environment and 2) determination of possible differences between these impacts depending on the urban biotope type to which these roadside green spaces belong. 
Programs IBM SPSS Statistics 21 and Microsoft Excel 2010 were used for data analysis and graphical presentation of research results. Parametric statistics was applied. Mean differences in the impact of green spaces were tested for different biotope types using one-factor analysis of variance (ANOVA). The Levene test was used for variance homogeneity testing, whereas the Tukey HSD test was used to obtain a display of statistically significant differences in the values of environmental factors, due to the best balance of type I and II errors.

\section{RESULTS AND DISCUSSION}

The representative green spaces which are the subject of this research (38 in total) were classified into three categories according to the Map of Belgrade biotopes ("Belgrade Green Regulation", Belgrade, 2007): urban fallows, green structures and thickets, groves and forests. Two roadside green spaces were classified into the urban fallows group, 26 of them in the group of green structures and 10 roadside green areas in the group thickets, groves and forests.

Table 1. The statistical parameters of mean differences in the investigated environmental factors for the analyzed urban biotope types

\begin{tabular}{|c|c|c|c|c|c|c|c|c|}
\hline \multirow{2}{*}{$\begin{array}{c}\text { Environ } \\
\text { mental } \\
\text { factor }\end{array}$} & \multirow{2}{*}{ Urban biotope type } & \multirow{2}{*}{ Mean } & \multirow{2}{*}{$\begin{array}{c}\text { Std. } \\
\text { Deviation }\end{array}$} & \multirow{2}{*}{ Std. Error } & \multicolumn{2}{|c|}{$\begin{array}{l}\text { 95\% Confidence } \\
\text { Interval for Mean }\end{array}$} & \multirow{2}{*}{ Min. } & \multirow{2}{*}{ Max. } \\
\hline & & & & & $\begin{array}{l}\text { Lower } \\
\text { Bound }\end{array}$ & $\begin{array}{l}\text { Upper } \\
\text { Bound }\end{array}$ & & \\
\hline \multirow{4}{*}{ 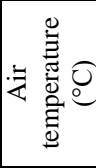 } & Urban fallows & 0,8194 & 0,42347 & 0,07058 & 0,6762 & 0,9627 & 0,10 & 1,70 \\
\hline & Green structures & 1,2064 & 0,62586 & 0,02046 & 1,1663 & 1,2466 & 0,10 & 3,40 \\
\hline & $\begin{array}{l}\text { Thickets, groves } \\
\text { and forests }\end{array}$ & 1,0994 & 0,63421 & 0,03343 & 1,0337 & 1,1652 & 0,10 & 4,70 \\
\hline & Total & 1,1670 & 0,62766 & 0,01720 & 1,1333 & 1,2008 & 0,10 & 4,70 \\
\hline \multirow{4}{*}{ 绿 } & Urban fallows & 1,0500 & 0,50681 & 0,08447 & 0,8785 & 1,2215 & 0,20 & 2,40 \\
\hline & Green structures & 1,9268 & 0,97226 & 0,03178 & 1,8644 & 1,9892 & 0,10 & 6,20 \\
\hline & $\begin{array}{c}\text { Thickets, groves } \\
\text { and forests }\end{array}$ & 1,9450 & 0,94552 & 0,04983 & 1,8470 & 2,0430 & 0,30 & 5,20 \\
\hline & Total & 1,9080 & 0,96564 & 0,02646 & 1,8561 & 1,9599 & 0,10 & 6,20 \\
\hline \multirow{4}{*}{ 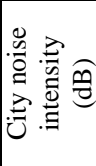 } & Urban fallows & 10,9333 & 1,24636 & 0,04106 & 7,5349 & 9,7317 & 6,00 & 15,40 \\
\hline & Green structures & 15,6411 & 4,58869 & 0,14999 & 15,3468 & 15,9355 & 4,00 & 29,90 \\
\hline & $\begin{array}{c}\text { Thickets, groves } \\
\text { and forests }\end{array}$ & 15,9806 & 5,20219 & 0,27418 & 15,4414 & 16,5198 & 4,20 & 28,80 \\
\hline & Total & 15,8137 & 4,75516 & 0,13029 & 15,5581 & 16,0693 & 4,00 & 29,90 \\
\hline \multirow{4}{*}{ 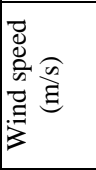 } & Urban fallows & 0,6708 & 0,58098 & 0,06500 & 0,4428 & 0,5127 & 0,10 & 1,10 \\
\hline & Green structures & 0,8470 & 0,72933 & 0,02384 & 0,8002 & 0,8938 & 0,10 & 6,20 \\
\hline & $\begin{array}{l}\text { Thickets, groves } \\
\text { and forests }\end{array}$ & 0,8608 & 0,73477 & 0,03873 & 0,7847 & 0,9370 & 0,10 & 4,90 \\
\hline & Total & 0,8597 & 0,74021 & 0,02028 & 0,8199 & 0,8995 & 0,10 & 6,20 \\
\hline
\end{tabular}

The highest mean difference in air temperature (Table 1) between the measurement points was recorded for green structures $\left(1.21 \pm 0.63^{\circ} \mathrm{C}\right)$, a slightly lower one for spaces belonging to thickets, groves and forests $\left(1.10 \pm 0.63^{\circ} \mathrm{C}\right)$, and the lowest one in the urban fallows group $\left(0.82 \pm 0.42^{\circ} \mathrm{C}\right)$.

Green spaces belonging to the biotope type thickets, groves and forests revealed the highest mean difference between measurement points for humidity $(1.95 \pm 0.95 \%)$, which was close to the value obtained for green structures 
$(1.93 \pm 0.97 \%)$, whereas the lowest value was recorded for urban fallows $(1.05 \pm 0.51 \%)$. Wind speed reduction was under the highest impact of green areas belonging to thickets, groves and forests with a mean difference of $0.86 \pm 0.73 \mathrm{~m} / \mathrm{s}$. A lower mean difference was recorded for green spaces belonging to green structures $(0.84 \pm 0.73 \mathrm{~m} / \mathrm{s})$, and the lowest one for the urban fallows group $(0.67 \pm 0.58 \mathrm{~m} / \mathrm{s})$. The highest mean difference in city noise intensity was recorded for green spaces belonging to thickets, groves and forests $(15.98 \pm 5.20 \mathrm{~dB})$, slightly lower one for green structures $(15.64 \pm 4.59 \mathrm{~dB})$, while the lowest one was found in the urban fallows group $(10.93 \pm 1.24 \mathrm{~dB})$.

A comparative analysis revealed that green spaces belonging to the urban biotope type thickets, groves and forests has the highest impact on humidity modification, noise intensity and wind speed, which was expected due to the significant presence of trees and shrubs. The samples from two green spaces belonging to the urban biotope type of urban fallows characterized by spontaneous ruderal vegetation or absence of woody plants proved to be the least efficient in the modification of investigated environmental factors. The results obtained are consistent with the study Wilmers (1988), which also found the highest impact of green structures on the reduction of air temperature in cities.

During two research years, mean air temperature reduction for the examined green spaces was $1.21 \pm 0.63^{\circ} \mathrm{C}$. When these results are compared to literature data, we can observe a partial proportional correlation. Depending on the author, air temperature reduction ranged from 2 to $8^{\circ} \mathrm{C}$ (Taha et al., 1991) and from 2 to $3^{\circ} \mathrm{C}$ (Bunuševac, 1962), or $1.3^{\circ} \mathrm{C}$ in $50 \%$ of measurements and $2.9^{\circ} \mathrm{C}$ in $15 \%$ of measurements performed in researches conducted by Amdrade and Vieira (2007). The discrepancies can be explained by different areas of studied green spaces. The listed authors investigated air temperature modification in urban parks and green spaces larger than 3ha, while $76.3 \%$ of green spaces in this study have an area below 1 ha.

Statistical significance in air temperature modification between different urban biotope types was confirmed at the level of 0.01 by the results of onefactor analysis of variance (Table 2). In addition, the Tukey HSD test revealed statistically significant differences in air temperature among all urban biotope types (Table 3). Statistical significance at the 0.01 level was found for urban fallows and green structures (Sig. $=0.000 ; \mathrm{p}<0.01$ ), whereas statistical significance at the 0.05 level (Sig. $=0.028 ; \mathrm{r}<0.05$ ) was recorded for urban fallows and thickets, groves and forests, as well as for green structures and thickets, groves and forests (Sig. $=0.016 ; \mathrm{p}<0.05$ ). The results of one-factor analysis of variance for humidity confirmed statistically significant differences between different urban biotope types at the 0.01 level (values of statistics were 49.276 (Welchtest) and 23.093 (Brown-Forsythetest), with a 0.000 significance (in both tests)). The Tukey HSD test revealed statistically significant differences in humidity modification between urban fallows and green structures (Sig. $=0.000$; $\mathrm{p}<0.01$ ) and urban fallows and thickets, groves and forests (Sig. $=0.000 ; \mathrm{r}<0.01$ ) at the 0.01 level, while no statistically significant differences were found between 
green structures and thickets, groves and forests (Sig.=0.949; r>0.05). These results suggest that thickets, groves and forests and green structures modify humidity more than urban fallows. Similar results were obtained by Sonne and Viera (2000), in a research of the impacts of bioclimatic urban forests. These authors found the highest cooling impact of green massifs in the city especially in terms of humidity, compared to urban green spaces with a notable absence of woody vegetation or those green spaces where woody plants occur only sporadically.

Table 2. One-factor analysis of variance of differences in the mean values of investigated environmental factors between the analyzed urban biotope types

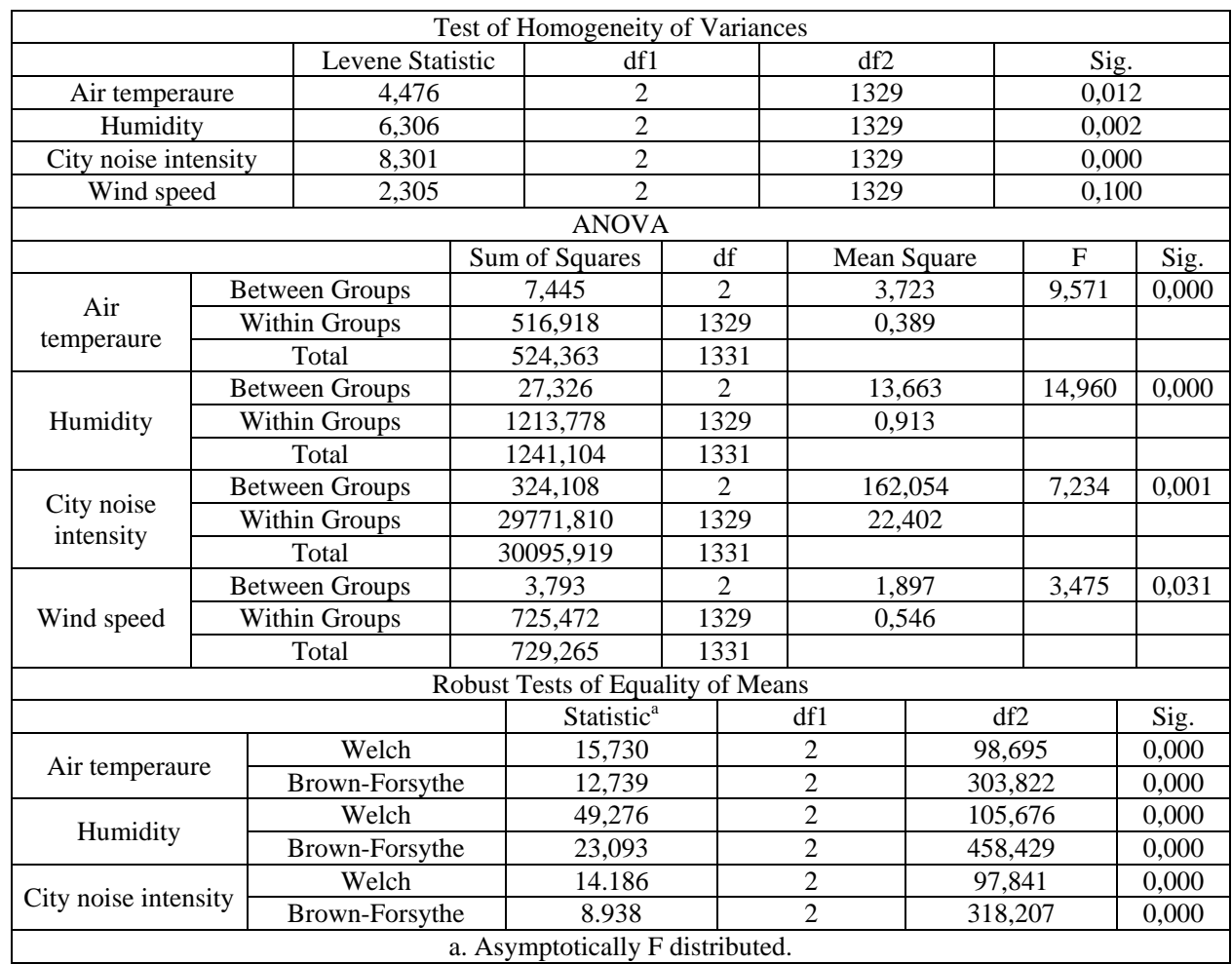

The results of one-factor analysis of variance for wind speed ( $\mathrm{f}$ value is 3.475 with a 0.031 significance) revealed statistically significant differences in wind speed reduction between the green spaces belonging to different urban biotope types. The tukey hsd test confirmed statistically significant differences between urban fallows and green structures (sig. $=0.023 ; \mathrm{p}<0.05$ ) and urban fallows and thickets, groves and forests (sig. $=0.038$; $\mathrm{p}<0.05$ ) at a significance level of 0.05 . However, no statistically significant differences (sig. $=0.951$; $r>0.05$ ) were found between the urban biotope types of green structures and thickets, groves and forests. Thickets, groves and forests and green structures reduce wind speed more than city fallows, primarily due to higher presence of woody plants. 
Table 3. Statistical parameters of the Tukey test - differences between the impacts of urban biotopes on the investigated environmental factors.

\begin{tabular}{|c|c|c|c|c|c|c|c|}
\hline \multirow{2}{*}{$\begin{array}{l}\text { Dependent } \\
\text { variable }\end{array}$} & \multirow{2}{*}{ (I) Biotope type } & \multirow{2}{*}{ (J) Biotope type } & \multirow{2}{*}{$\begin{array}{c}\text { Mean } \\
\text { Difference } \\
\text { (I-J) }\end{array}$} & \multirow{2}{*}{ Std. Error } & \multirow{2}{*}{ Sig. } & \multicolumn{2}{|c|}{$\begin{array}{l}\text { 95\% Confidence } \\
\text { Interval }\end{array}$} \\
\hline & & & & & & $\begin{array}{l}\text { Lower } \\
\text { Bound }\end{array}$ & $\begin{array}{l}\text { Upper } \\
\text { Bound }\end{array}$ \\
\hline \multirow{6}{*}{$\begin{array}{c}\text { Air } \\
\text { temperatur } \\
\mathrm{e}\end{array}$} & \multirow[b]{2}{*}{ Urban fallows } & Green structures & $-0,38697^{*}$ & 0,10592 & 0,001 & $-0,6355$ & $-0,1384$ \\
\hline & & $\begin{array}{c}\text { Thickets, groves } \\
\text { and forests }\end{array}$ & $-0,28000^{*}$ & 0,10902 & 0,028 & $-0,5358$ & $-0,0242$ \\
\hline & \multirow[b]{2}{*}{ Green structures } & Urban fallows & $0,38697^{*}$ & 0,10592 & 0,001 & 0,1384 & 0,6355 \\
\hline & & $\begin{array}{c}\text { Thickets, groves } \\
\text { and forests }\end{array}$ & $0,10697^{*}$ & 0,03868 & 0,016 & 0,0162 & 0,1977 \\
\hline & \multirow{2}{*}{$\begin{array}{c}\text { Thickets, groves } \\
\text { and forests }\end{array}$} & Urban fallows & $0,28000^{*}$ & 0,10902 & 0,028 & 0,0242 & 0,5358 \\
\hline & & Green structures & $-0,10697^{*}$ & 0,03868 & 0,016 & $-0,1977$ & $-0,0162$ \\
\hline \multirow{6}{*}{$\begin{array}{c}\text { Air } \\
\text { humidity }\end{array}$} & \multirow[b]{2}{*}{ Urban fallows } & Green structures & $-0,87682^{*}$ & 0,16231 & 0,000 & $-1,2577$ & $-0,4960$ \\
\hline & & $\begin{array}{c}\text { Thickets, groves } \\
\text { and forests }\end{array}$ & $-0,89500^{*}$ & 0,16705 & 0,000 & $-1,2870$ & $-0,5030$ \\
\hline & \multirow[b]{2}{*}{ Green structures } & Urban fallows & $0,87682^{*}$ & 0,16231 & 0,000 & 0,4960 & 1,2577 \\
\hline & & $\begin{array}{c}\text { Thickets, groves } \\
\text { and forests }\end{array}$ & $-0,01818$ & 0,05927 & 0,949 & $-0,1572$ & 0,1209 \\
\hline & \multirow{2}{*}{$\begin{array}{l}\text { Thickets, groves } \\
\text { and forests }\end{array}$} & Urban fallows & $0,89500^{*}$ & 0,16705 & 0,000 & 0,5030 & 1,2870 \\
\hline & & Green structures & 0,01818 & 0,05927 & 0,949 & $-0,1209$ & 0,1572 \\
\hline \multirow{6}{*}{$\begin{array}{l}\text { City noise } \\
\text { intensity }\end{array}$} & \multirow[b]{2}{*}{ Urban fallows } & Green structures & $2,99220^{*}$ & 0,80387 & 0,001 & 1,1061 & 4,8783 \\
\hline & & $\begin{array}{c}\text { Thickets, groves } \\
\text { and forests }\end{array}$ & $2,65278^{*}$ & 0,82734 & 0,004 & 0,7116 & 4,5940 \\
\hline & \multirow[b]{2}{*}{ Green structures } & Urban fallows & $-2,99220^{*}$ & 0,80387 & 0,001 & $-4,8783$ & $-1,1061$ \\
\hline & & $\begin{array}{c}\text { Thickets, groves } \\
\text { and forests }\end{array}$ & $-0,33942$ & 0,29353 & 0,480 & $-1,0281$ & 0,3493 \\
\hline & \multirow{2}{*}{$\begin{array}{l}\text { Thickets, groves } \\
\text { and forests }\end{array}$} & Urban fallows & $-2,65278^{*}$ & 0,82734 & 0,004 & $-4,5940$ & $-0,7116$ \\
\hline & & Green structures & 0,33942 & 0,29353 & 0,480 & $-0,3493$ & 1,0281 \\
\hline \multirow{6}{*}{$\begin{array}{l}\text { Wind } \\
\text { speed }\end{array}$} & \multirow[b]{2}{*}{ Urban fallows } & Green structures & $0,33077^{*}$ & 0,12548 & 0,023 & 0,0363 & 0,6252 \\
\hline & & $\begin{array}{c}\text { Thickets, groves } \\
\text { and forests }\end{array}$ & $0,31694^{*}$ & 0,12915 & 0,038 & 0,0139 & 0,6200 \\
\hline & \multirow[b]{2}{*}{ Green structures } & Urban fallows & $-0,33077^{*}$ & 0,12548 & 0,023 & $-0,6252$ & $-0,0363$ \\
\hline & & $\begin{array}{c}\text { Thickets, groves } \\
\text { and forests }\end{array}$ & $-0,01382$ & 0,04582 & 0,951 & $-0,1213$ & 0,0937 \\
\hline & \multirow{2}{*}{$\begin{array}{c}\text { Thickets, groves } \\
\text { and forests }\end{array}$} & Urban fallows & $-0,31694^{*}$ & 0,12915 & 0,038 & $-0,6200$ & $-0,0139$ \\
\hline & & Green structures & 0,01382 & 0,04582 & 0,951 & $-0,0937$ & 0,1213 \\
\hline
\end{tabular}

The results of one-factor analysis of variance for the environmental factor noise intensity revealed the values of statistics of 97.841 for the welch test and 318.207 for the brown-forsythe test with a 0.000 significance in both. That leads to a conclusion that the differences in noise intensity reduction between different urban biotope types are statistically significant at the 0.01 level. The tukey hsd test revealed statistically significant differences in noise intensity between urban fallows and green structures (sig. $=0.01 ; \mathrm{p}<0.05$ ) and urban fallows and thickets, groves and forests (sig. $=0.04 ; \mathrm{p}<0.05$ ), while no statistically significant differences were found between green structures and thickets, groves and forests (sig. $=0.480 ; r>0.05$ ).

Thickets, groves and forests are green spaces which contain grown trees and usually a well-developed second storey of trees and shrubs, and therefore 
have an impact on city noise intensity. In addition, Reethof (1973) argues that effective protection from city noise can be achieved with spontaneous natural vegetation or groves, especially if they contain trees. In addition, this author believes that groves containing grown trees along with the shrub storey tend to be particularly effective in the reduction of city noise intensity. The research of the environmental impacts of green spaces grouped according to their urban biotope type into green structures, urban fallows and thickets, groves and forests has revealed a particularly pronounced modification of the environmental factor air temperature. Chen and Wong (2006) also reported that the presence of urban vegetation, or the prevailing absence of greenery, has the highest impact on the modification of air temperature in the immediate urban environment, particularly in large city areas.

On the basis of the analysis conducted, it can be stated that urban fallows modify the investigated environmental factors less than green structures or thickets, groves and forests.

\section{CONCLUSIONS}

The study which explored the impact of 38 roadside green spaces grouped into three urban biotope types (green structures, urban fallows and thickets, groves and forests) along 15 main city routes in the Belgrade area on four environmental factors (temperature and humidity, noise intensity and wind speed) has revealed the following findings:

Roadside green spaces belonging to the biotope type thickets, groves and forests have the highest impact on the reduction and mitigation of the investigated environmental factors compared to green areas belonging to the urban biotope types of urban fallows and green structures. Urban fallows as a biotope type proved to be the least effective in the reduction of investigated environmental factors in the urban environment.

Compared to green areas belonging to the urban biotope types of urban fallows and thickets, groves and forests, green structures have the highest impact on the reduction of the environmental factor air temperature. Statistical significance at the level of 0.01 was found for the difference in air temperature reduction between urban fallows and thickets, groves and forests, whereas the statistical significance between green structures and thickets, groves and forests is at the 0.05 level. Differences in the reduction of the environmental factor humidity were statistically significant between urban fallows and green structures and urban fallows and thickets, groves and forests at the 0.01 level. Statistically significant differences for the environmental factor wind speed were found between urban fallows and green structures and urban fallows and thickets, groves and forests at the 0.05 level of significance.

When city noise intensity is concerned, statistically significant differences were found between urban fallows and green structures at the 0.01 level of significance and urban fallows and thickets, groves and forests at the 0.05 level of significance. However, statistically significant differences were not found between green structures and thickets, groves and forests in the reduction of the environmental factors of air humidity, wind speed and city noise intensity. 


\section{REFERENCES}

Amdrade H, Vieira R. 2007. Climatic study of an urban green spaces: the Gulbenkian park in Lisbon (Portugal), Finisterra, XLII, 84, 2007, pp. 27-46.

Aylor D. 1972. Noise reduction by vegetation and ground, Journal of the Acoustical Society of America 1972; 51(1):197-205.

Aylor E, Marks E. 1976. Perception of noise transmitted through barriers, Journal of Acoustical Society of America 1976; 59:397-400.

Bunuševac T. 1962. Funkcije zelenih površina naselja. - Šumarstvo, Beograd, god. XV, br.. 7-9, 1962. - str. 351-374.

Chen Y, Wong H. 2006. Thermal benefits of city parks, Energy and Building 2006; 38: 105-120.

Georgi N, Dimitriou D. 2010. The contribution of urban green spaces to the improvement of environment in cities: case Study of Chania, Greece, Building and Environment, 45:1401-1414.

Nowak DJ, Crane DE, Stevens, JC. 2006. Air pollution removal by urban treesand shrubs in the United States. Urban Forestry and Urban Greening, 4, 115-123.

Potchter O, Cohen P, Bitan A. 2006. Climatic behavior of various urban parks during hot and humid summer in the mediterranean city of Tel Aviv, Israel, International Journal of Climatology 2006; 26(12): 695-711.

Qiu L, Gao T, Gunnarsson A, Hammerb M, Roland von Bothmer. 2010. A methodological study of biotope mapping in nature conservation, Urban Forestry \& Urban Greening 9 (2010) 161-166.

Reethof G. 1973. Effect of plantings on radiation of highway noise, Journal of the Air Pollution Control Association. 23: 185-189.

Rosenberg J. 1974. Microclimate: The biological environment, Wiley, New York.

Sonne J, Viera R. 2000. Cool neighborhoods: the measurement of small scale heat islands, Proceedings of 2000 Summer Study on Energy Efficiency in Buildings, American Council for an Energy-Efficient Economy, 1001 Connecticut Avenue,Washington, DC, 2000.

Taha H, Akbari H, Rosenfeld A. 1991. Heat island and oasis effects of vegetative canopies: micrometeorological field measurements, Theory of Applied Climatolgy 44, 123-138.

Taha H.1997. Urban climates and heat islands: albedo, evapotranspiration, and anthropogenic heat, Energy and Buildings 25, 99-103.

Zoulia I, Santamouris M, Dimoudi A. 2009. Monitoring the effect of urban greenareas on the heat island in Athens, Environmental Monitoring and Assessment,156:27592.

Зелена регулатива Београда, Пројекат (IV фаза), Урбанистички завод Београда, Београд, (2007).

Urbanistički zavod Beograda, 2003, Generalni plan Beograda 2021, Beograd, Službeni list grada Beograda 27.

Wilmers F. 1988. Green for melioration of urban climate, Energy Buildings, 11: 289-299. 